\title{
Rules and routines as effective classroom management techniques on perceived students' academic achievement in shorthand in Edo state, Nigeria
}

\author{
Imafidon Adesuwa ${ }^{1}$, Airemwen Osariemen Joy ${ }^{2}$ \\ ${ }^{1}$ Department of Education, Benson Idahosa University, Benin City, Nigeria, ${ }^{2}$ Department of Business Education, \\ University of Benin, Benin City, Nigeria
}

\section{AbStract}

Purpose: The instruction of shorthand is facing serious criticism among teachers in the state of Edo in Nigeria. Doubts are being raised on the actual classroom management techniques used in teaching shorthand, leading to poor academic record of students. This study seeks to investigate rules and routines as effective classroom management techniques on perceived students' academic achievement in shorthand in Edo. Methodology: Two research questions and hypotheses were tested. We adopted descriptive survey research design. The participants included 134 teachers. The instrument for collecting data tagged Teachers' Classroom Techniques on Students Academic Achievement in Shorthand. The instrument used was validated by three experts. We used Cronbach's alpha to compute reliability. Findings: The findings revealed that classroom rules and classroom routines significantly influence students' academic achievement in shorthand. It also shows that teachers did not differ significantly on classroom management influence on student academic achievement in shorthand with respect to male and female teachers and rural and urban located teachers. Implications: Consequently, we recommended that institutions should encourage training and retraining of business studies teachers on classroom management techniques that would lead to increased academic achievement. Originality: There is dire need for an effective classroom management technique in shorthand to enable shorthand instruction to be efficient in schools.

Key words: Academic achievement, classroom management techniques, routines, rules, shorthand.

\section{INTRODUCTION}

Shorthand is a business education subject in office education. It is the art of representing spoken sounds with written signs. It is very useful in businesses, especially to secretaries, both from public and private organizations.
Using shorthand, they record minutes of meetings and telephonic conversations, which helps them greatly in their everyday work. Shorthand is taught right from junior secondary schools to tertiary institutions in Nigeria. Acquiring shorthand skills by a trained secretary makes him/her more relevant to businesses; this has made it an

*Corresponding author:

Airemwen Osariemen Joy, Department of Education, Benson Idahosa University, Benin City, Nigeria.

Phone: 08053445799. E-mail: aimafidon@biu.edu.ng

Received: 05 July, 2021; Accepted: 15 September, 2021

DOI: $10.18843 / \mathrm{ijcms} / \mathrm{v} 13 \mathrm{i} 1 / 01$ 
indispensable tool for every organization (Adeboye, 2000). A successful shorthand student is likely to have a brighter future ahead. For example, shorthand notes could be used legally; thus, even at courts, journalists use it extensively, because in most jurisdictions around the world, cameras and recorders are not allowed during trial. Moreover, it takes longer to get the transcripts of the verdicts, as they are not released immediately. In developed countries like the U.S and U.K., journalists are often paid a premium if they have their shorthand skills above a certain minimum speed requirement. Given this backdrop and utilities of shorthand skills, it is very important for teachers of business studies to create and maintain a productive classroom setting so as to attain the aim of the course. It requires some measures of teaching techniques or special methodology to impact on students offering skilled course like shorthand. Majority of these objectives are achieved through interactions between the students and teachers in the class; hence, the classroom needs proper planning (Adeboye, 2000). There are many classroom management techniques that can influence academic achievement of the business studies students. These include rules, routines, classroom organization, and expectation of student behavior, the teacher understanding the students, attention, affection, and praise. This study discusses a few of them that impinge on the achievement of students in a course like shorthand.

Classroom organization has been discussed across many research studies as one of the main factors that affect students' academic performance (Marzono and Pickering, 2003). Classroom management is seen as one of the actions teachers use to create an accommodating environment for academic and social-emotional learning of students (Everton and Emmer, 1982). It can also be seen as the instructors' skill to jointly manage time, space, resources, students' roles, and behaviors to provide an environment that encourages learning (Alberto and Troutman, 1986). Webster's Dictionary (2010) defines a rule as "a fixed standard that regulates conduct." The instructor should set some rules for the students to adhere to for effective teaching and learning of shorthand. For example, the shorthand teacher could inform the class that $\mathrm{s} /$ he does not tolerate late coming; any student coming late, would not be allowed to participate in the class on that particular day. Another example could be that the shorthand teacher tells the students that they must have their writing materials before entering the shorthand class; students, without their writing materials would not eligible to enter the class. Notably, within the classroom, rules are occasionally modified fit. Nonetheless, rules do create the confines for students' behavior and engagement (Nakamura, 2000); thus, constancy in their implementation is vital for effective classroom organization and management. A teacher ought to set rules for the students to adhere to for effective teaching and learning to go on. For example, a teacher could inform the class that $\mathrm{s} / \mathrm{he}$ does not tolerate talking when lessons are going on. Rules are one of the basic techniques that a teacher could use to curb the excess of students' misbehavior within the class. Routines on the other hand, are bendable than rules; they are precise ways of doing things. For example, some common routines include taking attendance, disposals of trash, labeling of work, turning in homework, making a change during or between class activities, genuine emergencies, and moving from one activity to another. Hence, routines shape the classroom environment (Wallace, 2011). It is necessary for teachers to regularly give the students cues/ routines that would remind them of suitable behavior. It is also necessary for a shorthand teacher to be excellent at planning and maintaining a good classroom environment, because of the skills involved in teaching shorthand (Wallace, 2011). Routines empower the recipients to be more accountable for their own behavior and knowledge in the classroom. They are precise ways of doing things that for the most part very little during the course of the lesson. For classrooms to operate efficiently and effectively, they need routines (McLeod et al., 2003). That is, routines include how to enter and exit the classroom, take attendance, lunch time, secure teaching resources, throw trash away, label work, submit homework, make a change during or between instructional activities, get to safety during drills and actual exigencies, and change from one action or place to another. Hence, routines determine the classroom environment. Efficient instructors use routines for daily tasks more than their ineffective colleagues (Stronge et al., 2003). They take their time at the beginning of the school session to teach the routines. After the routines are mastered, attention could be paid to the learning instructions (McLeod et al., 2003). Efficient instructors usually give students cues to remind them of behavior that is acceptable; they are generally good at planning and managing a positive classroom environment.

Students' academic achievement means performance outcomes that show the extent to which, a student has accomplished a particular goal that was the focus of activity in the instructional environment. Hence, academic achievement should be considered to be a comprehensive construct that comprises diverse areas of learning. Due to the fact that the field of academic achievement is very wide, and covers a variety of educational outcomes, the meaning of academic achievement is dependent on the indicators used to calculate it. Shorthand instructions have been facing serious criticisms among teachers in the state of Edo at Nigeria. Doubts are being raised on the actual classroom management techniques, used in teaching shorthand, which in turn, has led to poor academic achievement for the students. This study 
seeks to investigate rules and routines as effective classroom management techniques on perceived students' academic achievement in shorthand in Edo state, Nigeria. It is on the premise of this observed gap that this study focuses to ask: What are business studies teachers' classroom management techniques that could improve the perceived students' academic achievement in shorthand.

\section{Statement of the Problem}

The ability of teachers to organize classrooms and manage students' behavior is critical to achieving positive educational outcomes. Although sound classroom management does not guarantee effective instruction, it does establish the environmental context that makes good instructions possible. Unconducive learning environment in the public schools has posed serious problems to students' academic performance in shorthand over many decades ago. This trend has been on the increase; in fact, its prevalence has attracted the concern of teachers, parents, guidance counselors, and even academic researchers. Effective classroom management has been discussed extensively at educational seminars and workshops, with efforts aimed at bringing a lasting solution to the problem of students' poor academic performance encountered in secondary schools. In most cases, teachers become tired of using verbal instructions, and corporal punishment is meted out in an attempt to establish effective classroom management; but this method alone does not produce the desired results. Thus, it becomes necessary to examine effective classroom management techniques on perceived academic achievement in shorthand in Edo state, Nigeria.

\section{Purpose of the Study}

The study specifically looks to determine;

1. The extent teachers' classroom rules influence students' academic achievement in shorthand in public secondary schools at Edo.

2. The extent to which, classroom routines, introduced by teachers of business studies, influence students' academic achievement in shorthand in public secondary schools at Edo.

\section{Research Questions}

The following research questions were raised for this study;

1. What is the extent teacher's classroom rules influence achievement of students in shorthand in public schools in Edo state?

2. What extent do classroom routines introduced by teachers of business studies influence students' academic achievement in shorthand in public secondary schools in Edo state?

\section{Null Hypotheses}

The following null hypotheses were formulated:

1. There is no difference between male and female business studies teacher classroom management techniques on students' academic achievement in shorthand in public schools in Edo state

2. There is no significant difference between business studies teachers' in rural and urban secondary schools on classroom management techniques in Edo state.

\section{Research Design}

The study adopted descriptive survey design. This was used to elicit responses from respondents with questionnaire and analyzing data from only a few people considered representatives of the entire group.

\section{Population}

The respondents of this study included teachers of business studies in public secondary schools at Edo. In the entire state of Edo, the total population of teachers of business studies according to data obtained from Edo State Ministry of Education in 2020 was 134. Due to the relative small size of the population, we decided to use the entire population for the study.

\section{Instrument}

We employed a structured questionnaire as our study instrument. The questionnaire was titled "Classroom Management Techniques on Students Attendance and Academic Achievement;" it was designed by the researcher, based on insights gained from extant literature. The instrument was divided into two: Clusters A and B. Cluster A was used to elicit basic information on demographic variables of the recipients, while cluster $\mathrm{B}$ was further split into two: clusters B1-B2, covering the two research questions raised. Cluster B1 had 7 items that covered classroom rules on students' academic achievement. Cluster B2 had 6 items that covered classroom routines on students' academic achievement. The instrument had a 4-point Likert response level of very high extent (VHE) 4 points, HE 3 points, low extent (LE) 2 points, and very LE (VLE) 1 point. The respondents were required to choose only one option as their assessment of the situation for each question. 
Further, to determine the validity of the questionnaire, we adopted face and content validity. This was done by giving the instrument to the researcher's supervisor, along with two other experts in the Department of VTE, University of Benin, Benin city. The reliability of the data collection instrument was ensured by administering it to 20 teachers of business studies from the state of Delta. Notably, these teachers were not part of the main study; using Cronbach's alpha, the coefficients obtained herein, were 0.70 and 0.80 for the two clusters. These figures were considered high enough for the instrument to be reliable.

\section{Data Collection and Analysis}

Copies of the questionnaire were given to the respondents by the researcher and duly collected. For the research questions, descriptive statistics of mean and standard deviation were used. The z-test statistics was used to test the null hypotheses. The mean and standard deviation were regarded as the measure, which best represents the entire distribution of the data. Real limit of values was used for taking decisions on the items as follows.

\section{RESULTS}

Research question 1: What is the extent teachers' classroom rules influence academic achievement of student in shorthand in public schools in Edo state?

From the data in Table 1, results of mean responses of the respondents of classroom rules on student achievement shows that the mean ranges from 2.63 to 3.68 , and the variables $1-7$ were rated as HE. The results also show that all the variables on classroom rules have HE on student academic achievement in shorthand.

1. Research question 2: What extent does business studies teachers' classroom routines influence students' academic achievement in shorthand in public secondary schools in Edo state? From data in Table 2, we note that the mean ranges from 2.55 to 3.04 , and the

\begin{tabular}{lcc} 
Response categories & Rating & $\begin{array}{c}\text { Boundary } \\
\text { limit }\end{array}$ \\
VHE & 4 & $4.50-5.00$ \\
HE & 3 & $3.50-4.49$ \\
LE & 2 & $1.50-2.49$ \\
VLE & 1 & $0.50-1.49$ \\
\hline
\end{tabular}

The hypothesis will be accepted when the value obtained is $\geq 0.05$ variables $1-7$ were rated as HE. The results also show that all the variables on classroom routines have HE on student academic achievement in shorthand.

\section{Null Hypotheses 1}

There is no difference between male and female business studies teachers' classroom management techniques on students' academic achievement in shorthand in public schools in Edo state. From Table 3, the results indicate that there is no difference between male and female teachers' classroom management techniques on student academic achievement as $\mathrm{P}>0.05$. Notably, the number of male teachers was 40 , while the number of female teachers was 94. The mean for male teachers indicated 104.36 and that for female teachers showed 105.05. The standard deviation for male respondents stood at 10.60 and that of female respondents showed 10.65 . The degree of freedom showed 132 and the $t$-value indicated -0.253 . The null hypothesis was accepted based on the fact that $\mathrm{P}=0.801$ was $>0.05$.

\section{Null Hypothesis 2}

There was no significant difference between business studies teachers' in rural and urban public secondary schools in Edo state on students' academic achievement in shorthand. Results of the t-test in Table 4 show that there is no difference between rural and urban business studies teacher classroom management techniques on student academic achievement as $\mathrm{P}>0.05$. The number of rural located teachers was 43 , and the number of urban located teachers was 91 . The mean for rural located teachers indicated 106.10, and that for urban teachers showed 106.10. The standard deviation for male respondents stood at 10.60 , and that of female respondents showed 10.65. The degree of freedom showed 132 and the t-value indicated -0.253 . The null hypothesis thereby states that there is no difference between male and female teachers' classroom management techniques on academic achievement of students in shorthand in schools in Edo state which was accepted.

\section{FINDINGS}

1. Classroom rules technique highly influences students' academic achievement in shorthand

2. Classroom routines technique highly influence student academic achievement in shorthand

3. There is no significant difference between male and female business studies teachers' classroom management 


\begin{tabular}{|c|c|c|c|c|}
\hline S. No. & Item statement & Mean & SD & Remarks \\
\hline 1 & Enforcing classroom rules engender quiet and well behaved shorthand class & 2.95 & 1.02 & High extent \\
\hline 2 & $\begin{array}{l}\text { Obeying classroom rules creates a conducive environment for effective teaching } \\
\text { and learning of shorthand }\end{array}$ & 2.76 & 1.16 & High extent \\
\hline 3 & $\begin{array}{l}\text { Rules ensure disciplines class which improves students ability to follow the lesson } \\
\text { of shorthand }\end{array}$ & 2.63 & 0.98 & High extent \\
\hline 4 & $\begin{array}{l}\text { Available wide variety of rules reinforce by teachers enhances student academic } \\
\text { performances }\end{array}$ & 2.75 & 1.00 & High extent \\
\hline 5 & A well explained rule enhances the teaching and learning process of shorthand & 3.68 & 0.88 & High extent \\
\hline 6 & $\begin{array}{l}\text { A real and immediate feedback enhances classroom management, thereby } \\
\text { increases student academic performances }\end{array}$ & 2.65 & 1.24 & High extent \\
\hline \multirow[t]{2}{*}{7} & $\begin{array}{l}\text { A well-acknowledged and reinforced student behavior increases student } \\
\text { performance }\end{array}$ & 2.85 & 1.43 & High extent \\
\hline & Total & 2.94 & 1.06 & High extent \\
\hline
\end{tabular}

Source: Field study, 2020

Table 2: Mean and SD of respondents on classroom routines techniques on student academic achievement

\begin{tabular}{|c|c|c|c|c|}
\hline S. No. & Item statement & Mean & SD & Remarks \\
\hline 8 & Effective classroom routines in a shorthand class enhance student focus & 2.55 & 1.13 & High extent \\
\hline 9 & $\begin{array}{l}\text { Classroom routines makes the teaching of shorthand easier for student to } \\
\text { understand the lessons }\end{array}$ & 2.99 & 1.00 & High extent \\
\hline 10 & $\begin{array}{l}\text { Classroom routines positively influence the behavior of student and increase their } \\
\text { concentration }\end{array}$ & 2.58 & 1.23 & High extent \\
\hline 11 & $\begin{array}{l}\text { Routines help shorthand students to be more accountable for their behavior and } \\
\text { learning during instruction }\end{array}$ & 3.04 & 0.99 & High extent \\
\hline 12 & $\begin{array}{l}\text { The practice of routines in shorthand class provides corrective feedback to the } \\
\text { teacher }\end{array}$ & 2.79 & 1.01 & High extent \\
\hline \multirow[t]{2}{*}{13} & $\begin{array}{l}\text { Praise and encouragement given to the students enhances the successful } \\
\text { completion of routines in the shorthand classroom }\end{array}$ & 2.83 & 0.89 & High extent \\
\hline & Total & 2.80 & 1.04 & High extent \\
\hline
\end{tabular}

Source: Field study, 2020

Table 3: Results of t-test of difference between male and female business studies teachers classroom management techniques on student academic achievement

\begin{tabular}{lcccccc} 
Respondents & $\boldsymbol{n}$ & Mean & SD & Df & t-value & $\boldsymbol{P}$ \\
\hline Male & 40 & 104.36 & 10.60 & & & \\
Female & 94 & 105.05 & 10.65 & 132 & -0.253 & 0.801 \\
\hline
\end{tabular}

techniques on students' academic achievement in shorthand in Edo state

4. There is no significant difference between rural and

\begin{tabular}{|c|c|c|c|c|c|c|}
\hline & & & & & & \\
\hline Respondents & $n$ & Mean & SD & Df & $t$-value & $P$ \\
\hline Rural & 43 & 106.10 & 7.70 & & & \\
\hline Urban & 91 & 103.71 & 12.38 & 132 & -0.893 & 0.375 \\
\hline
\end{tabular}

urban business studies teachers' classroom management techniques on students' academic achievement in shorthand in Edo state. 


\section{DISCUSSION}

The extent business studies teachers' classroom rules techniques applied by business studies teachers influence students' academic achievement in shorthand. The findings from research question one have a HE on student academic achievement in shorthand in Edo state. In other words, classroom rules have a very high correlation with students' academic achievement in shorthand. These findings concur with Omomia and Omomia's (2014) study that reported that the ability of teachers to manage the students' behavior is critical in achieving positive educational outcomes. The extent of classroom routines applied by business studies' teachers do influence the students' academic achievement in shorthand. The findings from research question two reveal that the relationship between business studies teachers' classroom routines and students' academic achievement in shorthand in Edo state is very high. This implies that classroom routines applied by business studies teachers significantly influence students' academic achievement in shorthand. The findings of Aminu (2006) showed that there is a strong relationship between routines techniques and students' academic achievement in shorthand and students' academic achievement in shorthand is in consonance with the findings of this study. The result of the t-test analysis showed that the two groups of business studies teachers male and female and rural and urban did not differ significantly in their rating on the influence of classroom management techniques on students' academic achievement in shorthand in secondary schools in Edo state, hence, the null hypotheses was accepted.

\section{CONCLUSION}

Based on the findings of this study, we conclude that the classroom management techniques highly influence the students' academic achievement in shorthand. These techniques that include classroom rules and classroom routines should, therefore, be sustained by business studies teachers in the Edo state.

\section{RECOMMENDATIONS}

Deriving from the result of this study, we made the following recommendations:

1. Business studies teachers in Edo state should be able to apply classroom management rules technique. This would help in boosting academic achievement of students in shorthand

2. Business studies' teachers in Edo state should put classroom routines in place for effective and efficient teaching of shorthand, which will, in turn, improve their academic performance.

\section{AUTHOR'S CONTRIBUTION}

The first author wrote the introduction, background and references. The second author carried out the analysis, discussion and the conclusion part of the study..

\section{FINANCIAL SUPPORT}

There was no financial support from both the author institutions and NGO. The study was made possible with the effort of the authors.

\section{ACKNOWLEDGEMENTS}

The authors want to appreciate all those who contributed one way or the other to the success of this paper. Firstly, the researchers want to appreciate the principals whose schools were used to collect data. Secondly, the statistician who helped in coding in the data and finally my colleagues' whose contribution/discussion enhanced the research. Also the research assistants.

\section{CONFLICT OF INTEREST}

The authors have not declared any conflict of interests.

\section{REFERENCES}

Adeboye, K. (2000). Teachers work environment as correlate of classroom management in Ekiti state government secondary schools. Journal of Emerging Trends in Educational Research and Policy Studies, 2(4), 155-162.

Alberto, P., \& Troutman, A. C. (1999). Applied Behaviour Analysis for Teachers. $5^{\text {th }}$ ed. Upper Saddle River: NJ Merill. p19-23.

Aminu J. (2006). Issues and challenges In Nigerian Education In the $21^{\text {st }}$ century., Farfaru Journal of Mutti-Disciplinary studies Vol. I. Sokoto.

Everton, C. M., \& Emmer, E. T. (1982). Effective classroom management at the beginning of the school year in junior high classes. Journal of Psychology, 74, 458-498. 
Marzono, R. J., \& Pickering, D. J. (2008). Classroom Management that Works: Research Based Strategies for Every Teacher. Alexandria, VA: Association for Supervision and Curriculum Development. p1-8.

McLeod, J., Fisher, J., \& Hoover, G. (2003). The Key Element of Classroom Management: Managing Time and Space, Student Behavioural and Instructional Strategies. Alexandria, VA: ASCD. p. 54-58.

Nakamura, J. (2000). Classroom management and organization. In: Handbook for Qualities of Effective Teachers. $4^{\text {th }}$ ed., Vol. 65. Alexandria, VA: Association for Supervision and Curriculum Development. p. $102-105$

Omomia O. A. and Omomia T. (2014). Relevance of Skinner Theory of Reinforcement on effective school Evaluation in Management. Exceptional Children,
68(8), 345-359.

Stronge, J. H., Tucker, P. D., \& Ward, R. A. (2003). Improving Schools One Classroom at a Time: Impact of Effective Teaching. Talk Given at the Annual Project Stars Institute in Teachers Successful Strategies. United States: High Beam Research Inc.

Wallace, T. (2011). An eco-behavioural examination of high school classrooms that include students with disabilities. Exceptional Children, 68(8), 345-359.

Webster's Dictionary. (2010). Webster's Dictionary. Springfield, Massachusetts: Meriam Webster Publishing Company. p 390-392. 